\title{
Sleep-related breathing disorders in patients with Prader-Willi syndrome depending on the period of growth hormone treatment
}

\author{
Zaburzenia oddychania w czasie snu u pacjentów z zespołem Pradera-Willego \\ w zależności od okresu leczenia hormonem wzrostu
}

\author{
Agnieszka Lecka-Ambroziak¹, Małgorzata Jędrzejczak², Marta Wysocka-Mincewicz ${ }^{1}$, Mieczysław Szalecki' ${ }^{1,3}$ \\ ${ }^{1}$ Department of Endocrinology and Diabetology, The Children's Memorial Health Institute, Warsaw, Poland \\ ${ }^{2}$ Centre of Diagnosis and Therapy of Respiratory Diseases Pul-Med, Kielce, Poland \\ ${ }^{3}$ The Medicine and Health Sciences Faculty, University of Jan Kochanowski, Kielce, Poland
}

\begin{abstract}
Introduction: Sleep-related breathing disorders (SRBD) are commonly present in patients with Prader-Willi syndrome (PWS). Recombinant human growth hormone (rhGH) treatment is reported to improve breathing function in PWS, but the findings are not explicit. Material and methods: Screening polysomnography-polygraphy (PSG), assessing nasal respiratory flow, respiratory effort, and blood oxygen saturation, was used. Group $1-$ before rhGH therapy $(\mathrm{n}=11$, mean age 3.0 years); PSG was repeated after the start of rhGH therapy in a mean time of 0.9 years in six patients (Group 1a). Group $2-$ on rhGH treatment, for a mean time of four years $(n=17$, mean age 8.8 years). Group 3 - without rhGH therapy due to severe obesity $(\mathrm{n}=8$, mean age 13.1 years).

Results: Group 1 - mean apnoea-hypopnoea index (AHI) was 10.2, oxygen desaturation index (ODI) - 36.3, Group 1a - AHI 12.0, ODI 60.9, Group 2 - AHI 9.0, ODI 25.1, Group 3-AHI 8.2, ODI 22.0. ODI was significantly higher in Group 1a than in the other groups $(\mathrm{p}<0.005)$, but not strictly related to SRBD. The results in Group 2 did not differ significantly from those of Group 1.

Conclusions: Our study proves the high frequency of SRBD among PWS patients, with worsening of ODI after short-term rhGH therapy. (Endokrynol Pol 2017; 68 (6): 676-680)

Key words: sleep-related breathing disorders, Prader-Willi Syndrome, growth hormone treatment

\section{Streszczenie}

Wstęp: Zaburzenia oddychania w czasie snu (sleep-related breathing disorders, SRBD) występują często u pacjentów z zespołem Pradera-Willego (PWS). Opisywana jest poprawa funkcji oddechowych $w$ trakcie leczenia preparatem ludzkiego rekombinowanego hormonu wzrostu (GH), jednak dane te nie są jednoznaczne.

Materiał i metody: Przesiewowa ocena polisomnograficzna - poligrafia (PSG), oceniająca przepływ powietrza w trakcie oddychania, wysiłek oddechowy, saturację. Grupa 1 - przed leczeniem GH (n = 11, średni wiek 3 lata); PSG powtórzono po rozpoczęciu leczenia GH średnio po 0,9 roku u 6 pacjentów (grupa 1a). Grupa $2-\mathrm{w}$ trakcie leczenia GH, średni czas terapii 4 lata $(\mathrm{n}=17$, średni wiek 8,8 roku). Grupa 3 - bez leczenia GH z powodu znacznej otyłości ( $\mathrm{n}=8$, średni wiek 13,1 roku).

Wyniki: Grupa 1 - średni wskaźnik bezdech-spłycenie oddychania (apnea-hypopnea index, AHI) wynosił 10,2, wskaźnik desaturacji (oxygen desaturation index, ODI) - 36,3, group 1a - AHI 12,0, ODI 60,9, group 2 - AHI 9,0, ODI 25,1, group 3 - AHI 8,2, ODI 22,0.

ODI było znacząco wyższe w grupie 1a w porównaniu do pozostałych grup $(\mathrm{p}<0,005)$, ale nie wykazywało ścisłego związku z pozostałymi wskaźnikami SRDB. Porównanie wyników grupy 2 i grupy 1 nie wykazało różnic istotnych statystycznie.

Wnioski: Przedstawione wyniki potwierdzają wysoką częstość występowania SRBD u pacjentów PWS, z istotnym pogorszeniem ODI po krótkim okresie leczenia GH. (Endokrynol Pol 2017; 68 (6): 676-680)
\end{abstract}

Słowa kluczowe: zaburzenia oddychania w czasie snu, zespół Pradera-Willego, leczenie hormonem wzrostu

Grant: The study was sponsored by the Children's Memorial Health Institute, grant number S108/2009

\section{Introduction}

Prader-Willi syndrome (PWS) is the first recognised human genetic imprinting disorder. The main clinical features of PWS are hypotonia, psychomotor delay, difficulties in feeding during the first year of life, followed by lack of satiety and obesity developing from the early childhood, hypogonadotropin hypogonadism, short stature, and cognitive and behavioural dysfunction [1].

It is well documented that sleep-related breathing disorders (SRBD), both central apnoea (CA) and obstructive sleep apnoea (OSA), are commonly present in 
PWS patients. OSA is caused by several factors, such as: obesity, narrowing of upper airways and reduction of saliva excretion, adenoid/tonsillar hypertrophy, hypotonic breathing muscles, or scoliosis. CA might be caused by hypothalamic dysfunction [2]. Moreover, defensive mechanisms of circulatory and respiratory systems during development of hypoxia and hypercapnia are defective in PWS. Breathing disorders may negatively influence both physical and psychological wellbeing and social performance of PWS patients. They may also have impact on a shorter life expectancy result in PWS [3, 4].

Recombinant human growth hormone (rhGH) treatment has been reported to improve breathing function in PWS, mainly through the improvement of body composition and muscle strength, which may positively influence obstructive breathing disorders. However, the findings are not explicit [5-8]. Some data suggest that the first period of rhGH therapy can worsen SRBD $[9,10]$. The hypothesis includes the possibility of adenoid enlargement due to high insulin-like growth factor 1 (IGF1) levels after the rhGH initiation [9].

SRBD can be assessed by polysomnography studies (PSG). Screening polysomnography, also called polygraphy, includes assessment of respiratory flow, respiratory effort, and blood oxygen [11].

Classification of respiratory events in children according to the American Academy of Sleep Medicine (AASM) includes apnoea and hypopnoea rules [12-14]. The American Academy of Paediatrics (AAP) published clinical practice guidelines regarding obstructive sleep apnoea syndrome (OSAS) in children, in 2012 [15]. The normative values of polysomnography in children and adolescents are also included in a paper by Uliel in Chest 2004 [16]. The normal value for apnoea-hypopnoea index (AHI) is $<1 / \mathrm{hr}$. Mild $\mathrm{AHI}$ is scored when the value is between 1 and $5 / \mathrm{hr}$, moderate AHI is between 5 and $10 / \mathrm{hr}$ and severe AHI is more than $10 / \mathrm{hr}$. Desaturation value is scored as $\geq 4 \%$, minimal normal $\mathrm{O}_{2}$ saturation as $92 \%$. There is a range of various oxygen desaturation indexes (ODI) both in children and in adults. The British Thoracic Society defines normal ODI as $<15$ desaturations of $4 \% / \mathrm{hr}$, other studies criteria show the normal to mild ODI values as $\leq 15$ desaturations of $3 \% / \mathrm{hr}$ [17]. The desaturation value in children is mainly scored as $\geq 3 \%$, the normal range of ODI criteria in the paediatric population was also published as $<2.6$ desaturations of $4 \% / \mathrm{hr}$ [18-21].

The main aims of our study were to determine the frequency and specify the type of SRBD in our group of PWS patients, to analyse the influence of rhGH treatment on SRBD, and to compare the PSG results of rhGH-treated children and severely obese, non-treated PWS patients.

\section{Material and methods}

We present the PSG results in 36 PWS patients who were divided into three groups: before (Group 1) and after initiating rhGH treatment (Group 1a), on rhGH treatment for a mean time $4 \pm 3.0$ years (Group 2) and patients not treated with rhGH due to severe obesity (Group 3).

PSG was performed with Porti 6, as polygraphy, assessing nasal respiratory flow, respiratory effort by thoracic and abdominal strain gauges, and blood oxygen saturation using a pulse oximeter that allowed determination of AHI and differentiation of CA and OSA. All patients had assessment by an ENT physician (ear nose and throat specialist). The patients diagnosed with adenotonsillar hypertrophy had no surgery procedure prior to the sleep studies. Body mass index (BMI) was calculated as body weight (kilograms)/height (square metres) and expressed as Z-score according to the Polish national charts [22].

PSG was assessed by an experienced sleep specialist (MJ) according to the AASM rules. The study protocol was approved by the Ethical Committee of the Children's Memorial Health Institute. Written, informed consent was obtained from the patients' parents. The study was sponsored by the Children's Memorial Health Institute, grant number S108/2009.

Statistical analyses were performed using statistical software Statistica version 6.0. Results are expressed as mean values and standard deviations ( \pm SD). Parameters were evaluated with $t$-Student test for independent samples and paired t-Student test for parameters before and after short-term GH treatment. Correlations between the assessed parameters were evaluated with r-Pearson correlation and r-Spearman rank correlation depending on the type of distribution. P values $<0.05$ were considered statistically significant.

Some of the data were excluded from the analysis because the results were technically unreliable. We had to exclude the AHI and ODI results of one patient from Group 1 and the ODI results of two patients from Group 2.

\section{Results}

\section{Group 1 - patients before rhGH treatment}

Eleven children: six girls and five boys, mean age 3.0 years $( \pm 3.0)$, genotype: deletion of chromosome $15 q 11-13$ in seven patients, abnormality in methylation pattern, with an unidentified underlying genetic defect in four patients. Patients were mostly non-obese, mean BMI SDS 0.2 ( \pm 2.3 ). Two patients had BMI SDS $>2$ (4.9 and 3.5) and had not started rhGH therapy at that time. Mean IGF1 SDS was $-0.9( \pm 0.4)$.

Clinical characteristics are shown in Table I. Mean AHI was $10.2( \pm 6.9), \mathrm{AI}-6( \pm 4.5), \mathrm{HI}-4.2( \pm 2.9)$ (Table II). 
Index of CA was $2.4( \pm 3.1)$, OSA 2.3 ( \pm 1.2$)$, mixed apnoea 1.3 ( \pm 1.2 ) (Table III). Mean ODI was 36.3 ( \pm 19.2 ). Other desaturation characteristics are shown in Table IV.

The AHI in one patient with adenoid enlargement and obesity was scored as severe (AHI 19.4). One patient with laryngeal laxity and scoliosis had also severe SRBD, AHI 13.9 with Cheyne-Stokes respiration episodes.

\section{Group $1 a-$ six patients after short-term rhGH therapy}

rhGH therapy was started in six patients from Group 1: four girls and two boys. Mean age of the patients was 2.5 years $( \pm 0.8)$, mean BMI SDS -0.1 ( \pm 2.3$)$. PSG was repeated after the initiation of rhGH therapy in mean time 0.9 years ( \pm 0.7$)$. Mean rhGH dose was $0.024 \mathrm{mg} / \mathrm{kg} /$ /day ( \pm 0.004$)$, growth velocity $10.6 \mathrm{~cm} / \mathrm{yr}( \pm 3.7)$, mean IGF1 SDS 0.2 ( \pm 1.2$)$. The values of PSG were: AHI 12 ( \pm 5.8$)$, AI 9.1 ( \pm 4.7$),$ HI 2.9 ( \pm 2.5 ) (Table II). CA was 4.8 $( \pm 2.9)$, while OSA was $2.7( \pm 1.7)$ and mixed apnoea index was $1.6( \pm 1.8)$ (Table III). The only value that reached the statistical significance in comparison to Group 1 was ODI: mean ODI $60.9( \pm 25.4)$ vs. $36.3( \pm 19.2), p=0.045$ (Table IV). However, the high values of ODI in three patients were not directly related to the episodes of SRBD.

\section{Group 2-patients on rhGH treatment}

Seventeen patients: seven girls and ten boys, mean age 8.8 years $( \pm 5.1)$, genotype: deletion of chromosome $15 q 11-13$ in 12 patients, uniparental disomy in four patients, unbalanced chromosomal translocation between chromosome 15 and 21 with del 15q11-13 in one patient. Mean BMI SDS was 0.4 ( \pm 1.1$)$. rhGH therapy was continued for a mean time of four years, \pm 3.0 , mean rhGH dose was $0.019 \mathrm{mg} / \mathrm{kg} /$ day $( \pm 0.006)$, IGF1 SDS 1.0 ( \pm 0.9 ) (16 pts). The values of PSG were: AHI 9.0 $( \pm 6.5)$, AI 6.5 ( \pm 5.7), HI 2.5 ( \pm 1.6) (Table II). CA was $3.1( \pm 4.4)$, while OSA was $2.5( \pm 2.0)$ and mixed apnoea index was $0.9( \pm 0.8)$ (Table III). Comparison with Group 1 revealed no significant differences in the PSG values. Mean ODI was lower than in Group 1: 25.1 ( \pm 17.4) vs. 36.3 ( \pm 19.2$)$, but did not reach the statistical significance $(\mathrm{p}=0.145)$. Interestingly, ODI together with mean time of apnoea was significantly lower than in Group 1a: ODI 25.1 vs. $60.9, \mathrm{p}=0.001$ and mean time of apnoea $12 \mathrm{~s}$ vs. $10.2 \mathrm{~s}, \mathrm{p}=0.036$ (Table II, IV).

In three patients with high IGF1 levels AHI was scored as moderate to severe (6.3-14.3). Only one patient with high IGF1 value had adenoid hypertrophy.

\section{Group 3 - patients without rhGH therapy due to severe obesity}

Eight patients, four girls and four boys, mean age 13.1 yrs ( \pm 4.4$)$, genotype: deletion of chromosome 15q11-13 in six patients, uniparental disomy in two patients. All
Table I. Clinical characteristics of PWS patients

Tabela I. Charakterystyka kliniczna pacjentów PWS

\begin{tabular}{lllll}
\hline $\begin{array}{l}\text { Group of } \\
\text { PWS pts }\end{array}$ & $\mathbf{1}$ & $\mathbf{1 a}$ & $\mathbf{2}$ & $\mathbf{3}$ \\
\hline $\begin{array}{l}\text { Number of } \\
\text { pts }\end{array}$ & 11 & 6 & 17 & 8 \\
\hline Age & $3.0( \pm 3.0)$ & $2.5( \pm 0.8)$ & $8.8( \pm 5.1)$ & $13.1( \pm 4.4)$ \\
\hline BMI SD & $0.2( \pm 2.3)$ & $-0.1( \pm 2.3)$ & $0.4( \pm 1.1)$ & $5.3( \pm 1.3)$ \\
\hline IGF1 SD & $-0.9( \pm 0.4)$ & $0.2( \pm 1.2)$ & $1.0( \pm 0.9)$ & - \\
\hline $\begin{array}{l}\text { Tonsillar } \\
\text { hypertrophy }\end{array}$ & 2 & None & 4 & 3 \\
\hline Scoliosis & 1 & 1 & 6 & 2 \\
\hline
\end{tabular}

Group 1 - before rhGH therapy; Group 1a - after start of rhGH therapy in a mean time of 0.9 years; Group 2 - on rhGH treatment for a mean time of 4 years; Group 3 - without rhGH therapy

Table II. Type of sleep-related breathing disorders in PWS patients

Tabela II. Charakterystyka zaburzeń oddychania w czasie snu u pacjentów $P W S$

\begin{tabular}{|c|c|c|c|c|}
\hline $\begin{array}{l}\text { Group of } \\
\text { PWS pts }\end{array}$ & 1 & $1 \mathrm{a}$ & 2 & 3 \\
\hline $\mathrm{AHI}$ & $10.2( \pm 6.9)$ & $12.0( \pm 5.8)$ & $9.0( \pm 6.5)$ & $8.2( \pm 5.4)$ \\
\hline $\mathrm{Al}$ & $6( \pm 4.5)$ & $9.1( \pm 4.7)$ & $6.5( \pm 5.7)$ & $3.4( \pm 2.2)$ \\
\hline $\mathrm{HI}$ & $4.2( \pm 2.9)$ & $2.9( \pm 2.5)$ & $2.5( \pm 1.6)$ & $4.8( \pm 3.5)$ \\
\hline $\begin{array}{l}\text { Mean time } \\
\text { of apnoea } \\
\text { [sec] }\end{array}$ & $11.2( \pm 6.6)$ & $10.2( \pm 1.2)$ & $12( \pm 1.9)$ & $12.1( \pm 2.6)$ \\
\hline $\begin{array}{l}\text { Max time } \\
\text { of apnoea } \\
\text { [sec] }\end{array}$ & $28( \pm 17.8)$ & $\begin{array}{l}23.7( \pm \\
12.4)\end{array}$ & $27.9( \pm 8.6)$ & $29.4( \pm 18.3)$ \\
\hline $\begin{array}{l}\mathrm{AHI} \text { - apnoe } \\
\text { ndex correlat } \\
\text { desaturation; } \\
\text { herapy in a m } \\
\text { ime of } 4 \text { year }\end{array}$ & $\begin{array}{l}\text { oup } 1-\text { before } \\
\text { an time of } 0.9 \text { y } \\
\text { Group } 3-\text { wi }\end{array}$ & e rhGH therapy; & on rhGH treat & $\begin{array}{l}\text { L - apnoea } \\
\text { elated with } \\
\text { start of rhGH } \\
\text { lent for a mean }\end{array}$ \\
\hline
\end{tabular}

Table III. Type of apnoea

Tabela III. Rodzaje bezdechów

\begin{tabular}{lllll}
\hline $\begin{array}{l}\text { Group of } \\
\text { PWS pts }\end{array}$ & $\mathbf{1}$ & $\mathbf{1 a}$ & $\mathbf{2}$ & $\mathbf{3}$ \\
\hline CA & $2.4( \pm 3.1)$ & $4.8( \pm 2.9)$ & $3.1( \pm 4.4)$ & $0.9( \pm 0.5)$ \\
\hline OSA & $2.3( \pm 1.2)$ & $2.7( \pm 1.7)$ & $2.5( \pm 2.0)$ & $2.0( \pm 1.7)$ \\
\hline $\begin{array}{l}\text { Mixed } \\
\text { apnoea } \\
\text { index }\end{array}$ & $1.3( \pm 1.2)$ & $1.6( \pm 1.8)$ & $0.9( \pm 0.8)$ & $0.4( \pm$ \\
\hline
\end{tabular}

CA - central apnoea index; OSA — obstructive sleep apnoea index; Group 1 - before rhGH therapy; Group 1a - after start of rhGH therapy in a mean time of 0.9 years; Group 2 - on rhGH treatment for a mean time of 4 years; Group 3 - without rhGH therapy

patients were severely obese, mean BMI SDS $5.3( \pm 1.3)$. The values of PSG were: AHI 8.2 ( \pm 5.4$)$, AI $3.4( \pm 2.2)$, and HI $4.8( \pm 3.5)$ (Table II). OSA was $2.0( \pm 1.7)$, while 
Table IV. Desaturation characteristics

Tabela IV. Charakterystyka desaturacji

\begin{tabular}{|c|c|c|c|c|}
\hline $\begin{array}{l}\text { Group of } \\
\text { PWS pts }\end{array}$ & 1 & $1 a$ & 2 & 3 \\
\hline ODI & $36.3( \pm 19.2)$ & $60.9( \pm 25.4)$ & $25.1( \pm 17.4)$ & $22.0( \pm 13)$ \\
\hline $\begin{array}{l}\text { Mean } \\
\text { desaturation } \\
{[\%]}\end{array}$ & $88.6( \pm 3.5)$ & $85.7 \%( \pm 4.7)$ & $89.3( \pm 3.6)$ & $91.4( \pm 1.8)$ \\
\hline $\begin{array}{l}\text { Max } \\
\text { desaturation } \\
\text { [\%] }\end{array}$ & $65.8( \pm 6.3)$ & $61.5( \pm 1.1)$ & $65.0( \pm 7.3)$ & $66.6( \pm 3.5)$ \\
\hline $\begin{array}{l}\text { Mean } \\
\text { desaturation } \\
\text { time [sec] }\end{array}$ & $14.4( \pm 2.2)$ & $12.3( \pm 2.7)$ & $14.3( \pm 3.8)$ & $17.8( \pm 3.6)$ \\
\hline $\begin{array}{l}\text { Max } \\
\text { desaturation } \\
\text { time [min] }\end{array}$ & $1.3( \pm 0.7)$ & $1.1( \pm 0.2)$ & $1.3( \pm 0.4)$ & $1.4( \pm 0.6)$ \\
\hline $\begin{array}{l}\text { Mean } \\
\text { saturation } \\
{[\%]}\end{array}$ & $91.8( \pm 1.9)$ & $88( \pm 5.7)$ & $90( \pm 6.4)$ & $93.1( \pm 2.2)$ \\
\hline
\end{tabular}

CA was $0.9( \pm 0.5)$, and mixed apnoea index $0.4( \pm 0.3)$ (Table III). Mean ODI was $22.0( \pm 13)$, other values of desaturation are shown in Table IV. Comparison with Group 2 revealed significantly higher values of mean HI: 4.8 vs. $2.5, p=0.032$ and longer mean desaturation time: 17.8 vs. $14.3, p=0.043$. Comparing the results to Group 1a revealed for the first time in the study a significant difference in the results of AI. Interestingly, the AI was significantly lower in the obese patients: 3.4 vs. 9.1, $\mathrm{p}=$ 0.01 . Moreover, we found lower values of CA 0.9 vs. 4.8 , $\mathrm{p}=0.002$ and mean ODI: 22.0 vs. $60.9, \mathrm{p}=0.005$ and higher both mean and max desaturation values (91.4 vs. $85.7 \%$ and 66.6 vs. $61.5 \%, p=0.008$ and $p=0.005$, respectively). However, the mean time of desaturation was longer in the obese children (17.8vs. $12.3 \mathrm{~s}, \mathrm{p}=0.01$ ).

Comparing the results to the children before the $\mathrm{GH}$ treatment showed only longer mean desaturation time: $17.8 \mathrm{~s}$ vs. $14.4 \mathrm{~s}(\mathrm{p}=0.02)$.

\section{Results - all groups of patients}

Moderate SRBD with AHI $>5$ was diagnosed in 9 out of 10 in Group 1, in all patients in Group 1a, in 12 out of 17 patients in Group 2, and in 6 out of 9 in Group 3. Severe type SRBD with AHI > 10 was most commonly present in Group 2. The patients in Group 2 and 3 were much older than in Group 1; therefore, the clinical picture of the disease differed between these groups.

Interestingly, AHI did not differ significantly between the patients before and after initiation of rhGH as well as between the groups on rhGH therapy and untreated severely obese patients.
CA dominated in Group 1a and was significantly higher than in Group 3. There were no significant differences in OSA between Group 1 and 1a (Table III). These results do not validate the hypothesis that the initiation of rhGH causes worsening of OSA by growth of lymphoid tissue due to the rise in IGF1. The ODI value was significantly higher in Group 1a than in all other groups, but was not strictly related to SRBD. The mean saturation was below the minimal normal value in groups treated with $\mathrm{rhGH}$, reaching statistical significance between the Group 1a and 3 (88\% vs. 93.1\%, $\mathrm{p}=0.037$ ) (Table IV).

Analysis of the PSG data in relation to laryngeal history revealed significantly higher $\mathrm{HI}$ in the patients with adenoid enlargement ( 2.8 vs. $5.6, p=0.007$ ).

The PSG results in relation to orthopaedic history showed lower mean saturation values in patients with scoliosis ( 88 vs. $92 \%, \mathrm{p}=0.026$ ).

Further analysis of the group of patients treated with rhGH for a longer time unexpectedly showed a positive correlation between the time of rhGH therapy and AHI, AI, CA, both mean time of apnoea and hypopnea, as well as mean desaturation value. The only negative correlation applied to the mean time of desaturation. We observed a positive correlation between the IGF1 SDS values and both OSA and HI.

\section{Discussion}

SRBD were present in almost all PWS patients, mostly scored as moderate to severe. According to the results of our study the saturation values seem to deteriorate after short-term GH therapy with significantly higher ODI, but without differences in AHI and other PSG values. The results in the group treated with $\mathrm{GH}$ for a longer period do not differ significantly from the group before the rhGH therapy. However, there is a wide range of the patients' age, and therefore the data are difficult to interpret due to different clinical characteristics.

SRBD are part of the PWS characteristics [23]. Few papers are related to SRBD in relation to GH administration in PWS patients. A study by Haqq et al. showed a decreased $\mathrm{AI}$ and $\mathrm{HI}$ in 12 PWS patients after six months of rhGH treatment, but this trend was not statistically significant [5].

Another paper, by Festen et al., showed no significant difference in the PSG performed before and after six months of rhGH treatment in 35 PWS patients [6].

Miller et al. reported results of 25 PWS patients (16 children) after six weeks of rhGH therapy, with improvement of $\mathrm{AHI}$ in 14 patients, but worsening of obstructive events in six patients. Among them four had upper respiratory tract infections or adenotonsillar 
hypertrophy, with elevated IGF1 level in two patients [9]. In our study, the patients with high IGF1 levels had moderate to severe SRBD.

Williams et al. reported 37 PWS patients, both children and young adults, specifically selected for SRBD, some on rhGH treatment, with no significant differences between the group treated with rhGH and non-treated patients [24].

Those results are similar to our studies, as we did not find the statistical differences between AHI values in relation to rhGH treatment. Moreover, the worsening of ODI found in our group of short-term rhGH therapy was not strictly related to SRBD.

Consensus guidelines for rhGH therapy in PWS, published in JCEM 2013, include the need for close monitoring of any changes in breathing, particularly in sleep, and evaluation by oximetry or polysomnography, together with ENT assessment, within the first three to six months of the rhGH treatment [25]. It states that longer rhGH therapy causes improvement in respiratory muscle function $[5,9,25]$. However, the influence of rhGH on central respiratory drive is difficult to interpret [25-27].

\section{Conclusions}

Our study confirms the high frequency of SRBD among PWS patients, mostly of moderate or severe type. According to the results of polygraphy studies, only the desaturation index seems to deteriorate after short-term rhGH therapy. The results in the group treated with rhGH for a longer period do not differ significantly from the group before the rhGH treatment. The main differences between the children treated for a longer period and the obese untreated patients were higher values of hypopnoea index and longer mean desaturation time in the obese children. In conclusion, the results do not show a simple dependence between the SRBD and the period of rhGH therapy. It seems reasonable to perform sleep studies in all PWS patients, especially after initiating rhGH therapy.

\section{References}

1. Goldstone AP, Holland AJ, Hauffa BP, et al. speakers contributors at the Second Expert Meeting of the Comprehensive Care of Patients with PWS. Recommendations for the diagnosis and management of PraderWilli syndrome. J Clin Endocrinol Metab. 2008; 93(11): 4183-4197, doi: 10.1210/jc.2008-0649, indexed in Pubmed: 18697869.

2. Menendez AA. Abnormal ventilatory responses in patients with Prader-Willi syndrome. Eur J Pediatr. 1999; 158(11): 941-942, doi: 10.1007/ s004310051247, indexed in Pubmed: 10541954.

3. Eiholzer U. Deaths in Children with Prader-Willi Syndrome. Horm Res Paediatr. 2005; 63(1): 33-39, doi: 10.1159/000082745.

4. Bakker B, Maneatis T, Lippe B. Sudden Death in Prader-Willi Syndrome: Brief Review of Five Additional Cases. Horm Res. 2007; 67: 203-204.

5. Haqq AM, Stadler DD, Jackson RH, et al. Effects of growth hormone on pulmonary function, sleep quality, behavior, cognition, growth velocity, body composition, and resting energy expenditure in Prader-Willi syndrome. J Clin Endocrinol Metab. 2003; 88(5): 2206-2212, doi: 10.1210/ jc.2002-021536, indexed in Pubmed: 12727976.
6. Festen DAM, de Weerd AW, van den Bossche RAS, et al. Sleep-related breathing disorders in prepubertal children with Prader-Willi syndrome and effects of growth hormone treatment. J Clin Endocrinol Metab. 2006; 91(12): 4911-4915, doi: 10.1210/jc.2006-0765, indexed in Pubmed: 17003096 .

7. de Lind van Wijngaarden RFA, Siemensma EPC, Festen DAM, et al. Efficacy and safety of long-term continuous growth hormone treatment in children with Prader-Willi syndrome. J Clin Endocrinol Metab. 2009; 94(11): 4205-4215, doi: 10.1210/jc.2009-0454, indexed in Pubmed: 19837938.

8. Carrel AL, Myers SE, Whitman BY, et al. Long-term growth hormone therapy changes the natural history of body composition and motor function in children with prader-willi syndrome. J Clin Endocrinol Metab. 2010; 95(3): 1131-1136, doi: 10.1210/jc.2009-1389, indexed in Pubmed: 20061431

9. Miller J, Silverstein J, Shuster J, et al. Short-term effects of growth hormone on sleep abnormalities in Prader-Willi syndrome. J Clin Endocrinol Metab. 2006; 91(2): 413-417, doi: 10.1210/jc.2005-1279, indexed in Pubmed: 16317059.

10. Nixon GM, Rodda CP, Davey MJ. Longitudinal association between growth hormone therapy and obstructive sleep apnea in a child with Prader-Willi syndrome. J Clin Endocrinol Metab. 2011; 96(1): 29-33, doi: 10.1210/jc.2010-1445, indexed in Pubmed: 20943780.

11. Llombart M, Chiner E, Gómez-Merino E, et al. Sleep Apnea-Hypopnea Syndrome in a Pediatric Population: Differences Between Children With Tonsillar Hypertrophy and Those With Concomitant Disease. Arch Bronconeumol. 2007; 43(12): 655-661, doi: 10.1016/s15792129(07)60151-7.

12. Iber C, Ancoli-Israel S, Chesson JrA, et al. The AASM Manual for the scoring of sleep and associated events: rules, terminology and technical specifications, 1st ed. Westchester, Illinois. : 2007.

13. Wise MS, Nicholas CD, Grigg-Damberger MM, et al. Respiratory indications for polysomnography in children: an evidence-based review. Sleep. 2011; 34: 398A-398AW.

14. Aurora RN, Zak RS, Karippot A, et al. American Academy of Sleep Medicine. Practice parameters for the respiratory indications for polysomnography in children. Sleep. 2011; 34(3): 379-388, doi: 10.1093/ sleep/34.3.379, indexed in Pubmed: 21359087.

15. Marcus CL, Brooks LJ, Draper KA, et al. American Academy of Pediatrics, American Academy of Pediatrics. Diagnosis and management of childhood obstructive sleep apnea syndrome. Pediatrics. 2012; 130(3): 576-584, doi: 10.1542/peds.2012-1671, indexed in Pubmed: 22926173.

16. Uliel S, Tauman R, Greenfeld M, et al. Normal polysomnographic respiratory values in children and adolescents. Chest. 2004; 125(3): 872-878, doi: 10.1378/chest.125.3.872, indexed in Pubmed: 15006944.

17. Fietze I, Dingli K, Diefenbach K, et al. Night-to-night variation of the oxygen desaturation index in sleep apnoea syndrome. Eur Respir J. 2004; 24(6): 987-993, doi: 10.1183/09031936.04.00100203, indexed in Pubmed: 15572543

18. Scholle S, Wiater A, Scholle HC. Normative values of polysomnographic parameters in childhood and adolescence: cardiorespiratory parameters. Sleep Med. 2011; 12(10): 988-996, doi: 10.1016/j.sleep.2011.05.006, indexed in Pubmed: 22036104.

19. Cohen M, Hamilton J, Narang I. Clinically important age-related differences in sleep related disordered breathing in infants and children with Prader-Willi Syndrome. PLoS One. 2014; 9(6): e101012, doi: 10.1371/ journal.pone.0101012, indexed in Pubmed: 24979549.

20. De Cock VC, Diene G, Molinas C, et al. Efficacy of modafinil on excessive daytime sleepiness in Prader-Willi syndrome. Am J Med Genet A. 2011; 155A(7): 1552-1557, doi: 10.1002/ajmg.a.34047, indexed in Pubmed: 21671379.

21. Muzumdar H, Arens R. Diagnostic issues in pediatric obstructive sleep apnea. Proc Am Thorac Soc. 2008; 5(2): 263-273, doi: 10.1513/pats.200707113MG, indexed in Pubmed: 18250220.

22. Palczewska I, Niedźwiecka Z. Somatic development indices in children and youth of Warsaw. Med Wieku Rozw. 2001; 5: 1-118.

23. Lin HY, Lin SP, Lin CC, et al. Polysomnographic characteristics in patients with Prader-Willi syndrome. Pediatr Pulmonol. 2007; 42(10): 881-887, doi: 10.1002/ppul.20673, indexed in Pubmed: 17722117.

24. Williams K, Scheimann A, Sutton V, et al. Sleepiness and sleep disordered breathing in Prader-Willi syndrome: relationship to genotype, growth hormone therapy, and body composition. J Clin Sleep Med. 2008; 4(2): 111-118, indexed in Pubmed: 18468308.

25. Deal CL, Tony M, Hoybye $\mathrm{C}$, et al. Consensus guidelines for recombinant human growth hormone therapy in Prader-Willi syndrome. J Clin Endocrinol Metab. 2013; 98: E1072-E1087.

26. Lindgren $\mathrm{AC}$. increases $\mathrm{CO} 2$ response, ventilation and central inspiratory drive in children with Prader-Willi syndrome. Eur J Pediatr. 1999; 158: 936-940.

27. Katz-Salamon M, Lindgren AC, Cohen $\mathrm{G}$. The effect of growth hormone on sleep-related cardio-respiratory control. Acta Ped. 2012; 101: 643-648. 